DOI https://doi.org/10.30525/978-9934-26-148-0-21

\title{
ИННОВАЦИОННАЯ ДОКТРИНА МЕХАНИЗМА И УРОВНЕЙ РЕАЛИЗАЦИИ КОНКУРЕНТНОГО ПРАВОВОГО СТАТУСА СОЦИОСУБЪЕКТОВ
}

\author{
Тунтула А. С.
}

кандидат юридических наук, дочент, заместитель заведующего кафедрой гражданского и криминального права и процесса юридического факультета

Черноморского национального университета имени Петра Могиль

Белякова М. Д. соискатель высшего образования по специальности 081 Право квалификаиии магистра факультета экономики и права Международного классического университета имени Филиппа Орлика 2. Николаев, Украина

Разработанное и конструктивно развиваемое А.А. Кириченко, А.С. Тунтулой и Ю.А. Ланцедовой инновационная доктрина механизма и уровней реализации конкурентного правового статуса социосубъектов и иных тесно связанных с этим концепций в виде соответствующих статей перспективного Конституционного кодекса Украины, а равно любого иного государства мира [1, с. 77-81] более правильно представить таким образом :

I. «Состав социосубьектов», что в порядке объяснения понятий и терминов данного кодекса целесообразно представить следующим образом :

«Социосубьектами в контексте их правового статуса являются : 1. Физические лица. 2. Юридические лица. 3. Государство как суммативное образование физических и юридических лиц. 4. Межгосударственные учреждения как суммативные образования физических и юридических лиц различных государств» [1, с. 77].

II. «Сущность и перечень базисных составляющих категорий правового статуса социосубьектов», что также должно быть представлено в порядке объяснения понятий и терминов этого кодекса таким образом :

«Правовой статус социосубьектов состоит из таких базисных категорий : 
1. Право, представляющее собой возможность определенного социосубьекта воспользоваться конкретным положительным результатом общественного развития, когда отрицательный результат общественного развития может стать такой возможностью только при наличии Национальной программы по полному искоренению этого негативного результата или, по крайней мере, максимально возможной минимизации его уровня [1, с. 77$]$.

2. Свобода - при наличии акцента внимания на альтернативности и на беспрепятственности выбора перечисленными социосубьектами такой возможности [1, с. 78].

3. Обязанность, т.е. необходимость выполнить социосубьектом определенного установленного государством предписания, что поддерживается непосредственным (прямым) и/или делегированным государственным принуждением (юридической ответственностью).

4. Интерес, т.е. возможность социосубьекта использовать в своих целях такое право, свободу и/или обязанность другого социосубьекта)» $[1$, c. 78$]$.

III. «Внешняя и внутренняя сбалансированность правового статуса социосубьектов» :

«Сбалансированность правового статуса социосубьектов проявляется в том, что физические лица по правовому статусу равны от рождения, то есть принципиально имеют равный природный правовой статус.

Внутренний баланс правового статуса социосубьекта обеспечивается тем, что определенный объем его прав, свобод и интересов должен определять появление соответствующего объема его обязанностей.

Внешний баланс правового статуса социосубьектов проявляется в соотношении правового статуса одного социосубьекта относительно правового статуса другого социосубьекта, что определяется возрастом и состоянием здоровья человека, а также тем, какое именно направление общественной деятельности и с каким собственно объемом полномочий осуществляют эти социосубьекты» [1, с. 78].

IV. «Антиделиктная обязанность каждого гражданина предупреждать и пресекать правонарушения» :

«Каждый человек обязан предупредить или пресечь любое правонарушение, в т. ч. и криминальное, если при этом ему не могут быть причинены существенные и большего размера убытки, а субъект властных полномочий определенного антиделиктного органа обязан предупреждать и/или пресекать такие правонарушения в любой ситуации, за исключением очевидного достижения этой цели лишь ценой его жизни [1, с. 78]. 
При этом каждое вненормативное антисоциальное девиантное поведение физического лица должно быть поставлено в зависимость от причины превышения вненормативности в условиях такого усиленного применения государственного принуждения, позволяющего предупреждать возникновение такого рода деяния, выход которого за пределы нормы не обусловлен определенным психическим или иным заболеванием лица, в пределах нормы в условиях немедицинских учреждений специального типа (детские специальные учреждения, исправительновоспитательные или исправительно-трудовые учреждения и др.), а если вненормативность поведения обусловлена психическим или иным заболеванием человека - в условиях медицинских учреждений специального типа» [1, с. 78-79].

V. «Пределы правомерности и трехуровневый механизм реализации конкурентного правового статуса различных социосубьектов» :

«Пределы правомерности реализации правового статуса определенного социосубьекта заканчивается там, где в то же время и месте начинается нарушение любой базисной категории правового статуса другого социосубьекта, когда правотворческие органы обязаны избегать и искоренять конкуренцию правовых статусов различных социосубьектов (такого, который не может быть реализован каждой из сторон в одно и то же время и в одном и том же месте), а там, где это невозможно, допускать в виде исключения кратковременную конкуренцию их правовых статусов, применяя во всех иных случаях следующие три уровня механизма реализации конкурентных правовых статусов различных социосубьектов :

а) на первом из уровней следует попытаться реализацию конкурентных правовых статусов различных социосубьектов развести по времени или по месту [1, с. 79];

б) в случае невозможности достичь указанные цели переходят ко второму уровню реализации конкурентного правового статуса различных социосубьектов, согласно которому право преимущественной реализации такого статуса приобретает тот социосубьект, который имеет высший уровень мотивации к этому, исходя из общечеловеческих ценностей и принципа справедливости, а одновременная реализация правового статуса вторым социосубьектом уже приобретает в такой ситуации признаки соответствующего правонарушения [1, с. 79];

в) третий уровень реализации конкурентного правового статуса различных социосубьектов применяется в случае невозможности реализации первого из указанных уровней и при наличии примерно 
одинакового уровня такой мотивации у каждого из социосубьектов с конкурентным правовым статусом, когда право преимущественной реализации правового статуса приобретает социосубьект, первый заявивший о намерении реализовать и/либо уже приступил к реализации своего правового статуса $[1$, с. 79-80]. А если данная ситуация с этими же социосубьектами повторится, то преимущество, исходя из принципа справедливости, приобретает уже второй социосубьект, независимо от того, кто из них в этот раз первым заявил или уже приступил к реализации своего правового статуса» $[1$, c. $80-81]$.

Предложенный вариант механизма реализации конкурентного правового статуса позволяет решать любые спорные антиделиктные ситуации, наиболее актуальным из которых являются попытки отдельных физических лиц продемонстрировать свою политическую или иную позицию на центральных улицах и/либо в иных общественных местах и/или вблизи административных зданий органов высшей государственной власти в соответствии с требованиями ст. 39 Конституции Украины, согласно которым граждане имеют право собираться мирно, без оружия, проводить собрания, митинги, походы и демонстрации, о проведении которых заблаговременно уведомляются органы исполнительной власти или органы местного самоуправления, а ограничения относительно реализации этого права может устанавливаться судом в соответствии с законом и только в интересах национальной безопасности и общественного порядка - с целью предотвращения беспорядков или криминальных правонарушений, для охраны здоровья населения или защиты прав и свобод иных людей» [1, c. 81].

VI. «Алогичность использования прав, свобод, обязанностей и/или интересов одного социосубьекта за счет соответствующего нарушения определенной базисной категории правового статуса другого социосубьекта» : «Правонарушением является использование прав, свобод, обязанностей и/или интересов одного социосубьекта за счет соответствующего нарушения определенной базисной категории правового статуса другого социосубьекта, в любом случае, обеспечения правового статуса определенной группы меньшинства социосубьектов за счет соответствующего нарушения определенной базисной категории правового статуса аналогичной группы большинства социосубьектов, за исключением случаев, предусмотренных и должным образом компенсационно урегулированных законом» [1, с. 81].

\section{Литература :}


1. Кириченко О. А., Тунтула О. С., Ткач Ю. Д. Інновації юриспруденції в забезпеченні журналістської галузі права та медіабезпеки : монографія. Варшава : RS Global Sp.z O.O., 2021. 98 c. URL: https:// monographs.rsglobal.pl/index.php/rsgl/catalog/book/40

2. Конституція України : закон України від 28 черв. 1996 р. № 254к/96-ВР. Відомості Верховної Ради України (ВВР), 1996, № 30, ст. 141, із змінами, згідно із законом № 27-ІХ від 3 вер. 2019 р., ВВР, 2019, № 38, ст. 160. URL : http://zakon2.rada.gov.ua/laws/show/254к/96-вр 